\title{
Encarando a atrocidade: a vergonha e sua ausência
}

\author{
Facing atrocity: shame and its absence
}

\section{Phil Hutchinson}

\section{Tradução de Willian Martini, Tiago Azambuja, Janyne Sattler}

Universidade Federal de Santa Maria (UFSM), Santa Maria, RS, Brasil

\section{Resumo}

Neste artigo, concentro-me sobre quatro variedades possíveis de ausência da vergonha. Minha esperança é a de que a reflexão sobre essas variedades possa, de alguma maneira, nos dar uma imagem mais completa acerca do papel que a vergonha desempenha sobre nosso caráter moral e nas discussões a respeito da atrocidade. Observo que a vergonha que emerge de uma exposição à atrocidade pode em parte constituir aquilo que nos leva a identificar o evento como atroz. Prossigo então argumentando que quando a vergonha está ausente, esta ausência pode servir para nos cegar para a atrocidade que está à nossa frente, e que é nossa tarefa tentar evitar. Sentir vergonha faz parte de ver a atrocidade pelo que ela é de uma maneira apropriada emocionalmente engajada. Ela é, portanto, uma parte vital de ser humano, e sua ausência em certos casos é uma insuficiência demasiadamente humana de humanidade.

Palavras-chave: Vergonha. Atrocidade. Emoções.

* WM: Mestrando em Filosofia, e-mail: willianmartini@hotmail.com

TA: Graduando em Filosofia, e-mail: tiagoethos.koinonia@gmail.com

JS: Doutora em Filosofia, e-mail: janynesattler@gmail.com 


\section{Abstract}

In this paper I focus on four varieties of shame-absence. My hope is that reflection on these varieties of shame-absence will go some way to giving us a more complete picture of the role that shame plays in our moral character and in discussions of atrocity. I note that the shame that emerges from an exposure to atrocity can be in part what leads us to identify the event as atrocious. I progress to argue that when shame is absent, this absence can serve to blind us to the atrocity that is before us and that is ours to work to prevent. Feeling shame is part of seeing the atrocity for what it is in an appropriate emotionally-engaged manner. It is thus a vital part of being human, and its absence in certain cases is an all-too-human failure of humanity.

Keywords: Shame. Atrocity. Emotions.

Eram quatro jovens soldados a cavalo, que agiam cautelosos, com as metralhadoras embraçadas, ao longo da estrada que demarcava os limites do campo. Quando chegaram ao arame farpado, detiveram-se, trocando palavras breves e tímidas, lançando olhares trespassados por um estranho embaraço, para observar os cadáveres decompostos, os barracões arruinados, e os poucos vivos. [...]

Não acenavam, não sorriam; pareciam sufocados, não somente por piedade, mas por uma confusa reserva, que selava as suas bocas e subjugava os seus olhos ante o cenário funesto. Era a mesma vergonha conhecida por nós, a que nos esmagava após as seleções, e todas as vezes que devíamos assistir a um ultraje ou suportá-la: a vergonha que os alemães não conheceram, aquela que o justo experimenta ante a culpa cometida por outrem, e se aflige que persista, que tenha sido introduzida irrevogavelmente no mundo das coisas que existem, e que a sua boa vontade tenha sido nula ou escassa, e não the tenha servido de defesa.

Primo Levi ${ }^{1}$

\footnotetext{
N. de T.: Facing atrocity: shame and its absence, de autoria de Phil Hutchinson, foi originamente publicado em Passions in Context - International Journal for the History and Theory of Emotions, 2011, n. 2. Disponivel em: <http://www. passionsincontext.de/index.php?id=775>. A fim de dirimir certas ambiguidades e imprecisões de tradução, algumas poucas palavras estão acompanhadas de seus termos originais entre colchetes quando da primeira vez em que aparecem no texto.
}

Rev. Filos., Aurora, Curitiba, v. 28, n. 44, p. 689-716, maio/ago. 2016 


\section{Introdução}

Muito tem sido dito a respeito da vergonha sentida como resposta à exposição à atrocidade, e grande parte destes escritos tem sido a respeito de como a emoção nos constrange de uma maneira que parece injusta ou desleal. A fenomenologia da vergonha aproxima-se da fenomenologia da culpa (guilt), embora a primeira frequentemente afete ou recaia também sobre aqueles que de nada são culpados. Isso nos fornece amplas bases para focarmos nossa atenção sobre a natureza negativa da vergonha como uma emoção.

Em contrapartida, relativamente pouco tem sido dito a respeito da ausência da vergonha: sobre aqueles momentos nos quais esperaríamos que a vergonha estivesse presente, situações nas quais nós naturalmente ou automaticamente esperaríamos que uma pessoa tivesse vergonha, ou situações que acreditamos merecer a atribuição da vergonha onde ela esteja ausente. Essas situações poderiam ser aquelas em que a ausência da vergonha parece "exigir" uma explicação. No que se segue, serão sugeridas quatro maneiras segundo as quais tais situações podem ser caracterizadas. E argumentaremos que duas delas são particularmente pertinentes quando se trata de compreender a vergonha e a atrocidade.

\section{Compreendendo a vergonha}

A vergonha possui muitos disfarces ou, talvez seja melhor dizer, o termo "vergonha" captura uma família disfuncional (dysfunctional Family) de experiências emocionais. Alguns casos de vergonha parecem ser automáticos - afetivos, para usar a terminologia filosófica/psicológica encontrada na literatura. Outros casos são claramente dados pelo viés da reflexão, por exemplo, sobre o tipo de indivíduo que alguém é e

Algumas pessoas generosamente leram e ofereceram observações a respeito deste artigo. Eu gostaria de aproveitar esta oportunidade para agradecê-las. São elas: Luisa Samedo, Rupert Read, Michael Loughlin, Thomas Brudholm e um revisor anônimo. Claro, todos os erros são de minha responsabilidade.

2 Primo Levi, A Trégua. Tradução Marco Lucchesi. São Paulo: Companhia das Letras, 2010, p. 10. 
sobre o tipo de indivíduo que alguém gostaria de ser, ou que alguém gostaria que os outros pensassem que ele é. Na terminologia das disciplinas acadêmicas de psicologia e filosofia, isso tem levado a uma identificação quase exclusiva da vergonha, a emoção, como cognitiva: ao invés de ser meramente instanciada por um desencadeador ambiental, a vergonha emerge do ato de cognição.

Porque muitos dos casos da vergonha parecem ser irredutivelmente reflexivos, ela tem sido retratada como uma emoção distintamente cognitiva (ou mesmo como um caso paradigmático). Apesar de outras diferenças, Gabriele Taylor (1985), Martha Nussbaum (2003), e Paul E. Griffiths (1997), concordam em categorizar a vergonha como uma emoção cognitiva. Eu gostaria de sugerir que não temos necessidade de aceitar tal raciocínio, já que ele parece repousar sobre o pressuposto de que os termos relativos à emoção, tais como a vergonha, devem ser categorizados, indexados ou classificados em tipos conforme eles sejam afetivos ou cognitivos ${ }^{3}$. Mas a vergonha, assim como o medo, pode acometer alguém de uma maneira afetiva ou emergir da reflexão. A vergonha, assim como o medo, pode ser afetiva ou cognitiva.

O conceito de "vergonha" pode, por vezes, ser de difícil apreensão ou significação. Não é que tenhamos dificuldade em alinhar a expressão com o contexto ou situação em que ela se manifesta, como no caso da vergonha, que é expressa por Primo Levi (2000) segundo o contexto que lhe dá origem. Tal como testemunhada por Levi, a vergonha pode nos parecer uma resposta emocional inteiramente natural diante da situação em que ele se encontrava. Mas o que parece de fato haver de enigmático no tocante à vergonha encontra-se antes em sua explicação. Os escritos de Levi testemunham a sua dificuldade em explicar a sua vergonha (ver Levi 1998, para um extenso capítulo em que ele luta por explicar aquela vergonha já anteriormente testemunhada em If This Is a Man). Pode parecer que sabemos, em um nível profundo que os sobreviventes de traumas extremos carregam a vergonha como uma

3 Eles são às vezes categorizados de acordo com distinções cognatas, tais como programa afetivo/cognitivo elevado — affect programme/higher cognitive - (primeiro Griffiths), simples/complexo (último Griffiths), emoções afetivas/emoções de autoavaliação (Gabriele Taylor). 0 que todas estas categorizações têm em comum é a representação da vergonha como sendo essencialmente reflexiva e, assim, cognitiva.

Rev. Filos., Aurora, Curitiba, v. 28, n. 44, p. 689-716, maio/ago. 2016 
marca de sua sobrevivência àquele trauma, ao mesmo tempo em que também procuramos compreender como ou por que envergonham-se, ou por que deveriam envergonhar-se por terem sobrevivido.

Sugeri alhures a possibilidade de uma estrutura para se compreender a vergonha a qual, acredito, vem ajudar a resolver esta dificuldade, para aqueles que assim a consideram. Eu chamei esta estrutura de "cognitivismo de apreensão-do-mundo" ("world-taking cognitivism"), mas a nomenclatura não é importante ${ }^{4}$. O ponto é o modo como, enquanto observadores, nós podemos compreender uma expressão emocional que nos havia até agora desorientado, ao engajarmo-nos em algo que poderíamos chamar de "redescrição" filosófica do cenário. Tal "redescrição" envolve trazer à vista a relação entre, por um lado, a conceptualização do estado de coisas em que se encontra aquele que expressa a vergonha e, por outro lado, o seu caráter. A sugestão é a de que a vergonha pode ser tornada inteligível ao fazermos uso de tal "redescrição". Assim, procuramos tornar manifestas as "relações internas" mantidas, por um lado, entre a conceptualização do estado de coisas no qual se encontra uma pessoa com esse ou aquele caráter e, por outro lado, o fato de ela ter vergonha. Dito de outra maneira, uma pessoa de um caráter particular em uma situação tal irá sempre envergonhar-se, pois faz parte do significado desta situação que para tal pessoa essa seja uma situação vergonhosa, e a situação vergonhosa da qual ela é uma parte constitutiva inevitavelmente a afeta. A história que se pode contar a respeito do caráter do "expressor" será informada por sua enculturação - sobre o modo como sua iniciação e sua relação para com sua(s) cultura(s) contribui para a formação do seu caráter.

A ideia é que, ao invés de ver as emoções de uma maneira que já pareceu natural para muitos (incluindo escritores de outra forma tão divergentes quanto Gabriele Taylor e Paul Griffiths), como sendo categorizáveis em emoções afetivas e emoções cognitivas, ou afetivas e complexas, nós poderíamos, antes, vê-las contra o pano de fundo do que poderíamos chamar de "especificidade cultural". Pois, se uma emoção particular pode ser alternadamente afetiva e cognitiva, então

4 Ver Hutchinson 2008, particularmente capítulos 3 e 4. 
uma tal classificação ou bem está errada $\left(\right.$ Griffiths $\left.^{5}\right)$ ou é potencialmente enganosa (Taylor) ${ }^{6}$.

Agora, isso significa dizer que uma emoção tal como a vergonha exige um nível mais elevado de especificidade cultural do que o faz, por exemplo, a emoção da repulsa (disgust). Se compreendemos isto como sendo uma maneira de distinguir diferentes emoções, então podemos ver porque tem parecido natural categorizar as emoções em duas classes (ou tipos): complexas (cognitivas) e afetivas. Podemos ver também porque esta é uma divisão em última análise enganosa e imprecisa. Pois esta categorização sugere que a vergonha não pode ser afetiva já que ela não toma o seu lugar nesta categoria - e que, por exemplo, a repulsa não pode originar-se de uma mera fria reflexão. Enquanto uma emoção tal como a vergonha baseia-se, para sua instanciação, em características culturalmente dadas de razoável alto nível e, assim, potencialmente, culturalmente específicas, emoções tais como a repulsa ou o medo são tipicamente indexadas a características mais básicas ou, até mesmo, - poderíamos dizer - biológicas. Eu não quero com isso sugerir que as primeiras estejam mais propensas a ser complexas ou cognitivas e, as últimas afetivas. Não há conexão lógica entre o nível de especificidade cultural e a questão de saber se um episódio emocional envolve pensamento (ou cognição) ou não. Basta dizer que uma emoção que opera em um nível mais elevado de especificidade cultural e que está, assim, ancorada primariamente no desenvolvimento cultural da pessoa que a experimenta, será uma emoção que proporcionará uma maior oportunidade para a reflexividade. Isto, eu sugiro, é o que tem levado à tendência a separar as emoções em linhas cognitivas e afetivas. É também porque tal tentativa estará sempre em desacordo com a

5 Griffiths classifica as emoções em dois tipos naturais e um pseudotipo de emoção socialmente construída e, assim, uma pseudoemoção. Na classificação de Griffiths, a vergonha toma o seu lugar no tipo complexo de emoções. Neste sentido, reconhecer que a vergonha pode ser tanto afetiva quanto complexa, significa, ou bem reconhecer uma falha na classificação ou sugerir que há dois tipos diferentes de emoção compreendidos pelo termo vergonha.

6 Taylor identifica a vergonha como uma das emoções de autoavaliação, juntamente com a culpa, 0 orgulho e o remorso. Isto, sugiro, é enganoso na medida em que é concebível que a vergonha seja sentida também a partir de uma concepção completamente internalizada do eu [self], a qual não concorda com a autoavaliação expressa pela própria pessoa. Podemos em parte dizer que é isto o que dá origem àquele conflito com a vergonha que é tão familiar aos que a experimentam como resposta a um trauma. 
fenomenologia da emoção. Já que, por mais culturalmente específicas que sejam as características sobre as quais possa basear-se uma emoção, elas podem sempre ser internalizadas e tornadas habituais - parte da natureza de uma pessoa.

Poderíamos colocar tudo isso em termos aristotélicos. Enquanto parece perspícuo indexar a repulsa ou o medo à nossa primeira natureza (nossa natureza biológica), parece igualmente perspícuo indexar a vergonha à nossa segunda natureza. Dito de outra forma, os recursos sobre os quais nos baseamos ao oferecer uma explicação para a vergonha sentida por alguém (ou por nós mesmos), serão aqueles que se relacionam com o tipo de caráter que a pessoa tem (ou que nós temos) - embora este não seja sempre especificamente o seu caráter moral. Em contrapartida, os recursos sobre os quais nos baseamos para explicar a repulsa ou o medo serão, mais frequentemente, aqueles que se relacionam com o tipo de criaturas que nós somos relativamente à nossa vulnerabilidade física, e aos traços que desenvolvemos enquanto espécie de modo a permitir a nossa sobrevivência e o nosso florescimento (flourishing).

Aqui, há dois pontos que são importantes.

Primeiro, eu não pretendo aqui propor qualquer maneira alternativa de se categorizar as emoções, seja em classes ou em tipos. Eu antes estou tentando explicar porque sempre nos pareceu natural pensar que se poderia categorizar as emoções da maneira tradicional e porque tentar fazê-lo estaria em desacordo com os fenômenos.

Segundo, a vantagem deste modo de se considerar as emoções é que ele permanece neutro relativamente à fenomenologia de episódios emocionais particulares, na medida em que não implica em uma determinação teorética prévia do episódio emocional como afetivo ou "cognitivo". (Embora possa nos proporcionar uma determinação "empiricamente informada" posterior do episódio como afetivo ou "cognitivo").

A ideia é resistir à tentação de fornecer uma teoria da vergonha, ao buscar a melhor perspectiva para compreender a vergonha de uma pessoa. O que é significativo em nossa compreensão da emoção é o modo como esta pessoa apreende (takes in) o mundo. Tomado desde a perspectiva do "cognitivismo de apreensão-do-mundo", o estado 
emocional é uma maneira de ver (apreender) o mundo: estar atento (being alive to) para um aspecto do mundo. A vergonha que alguém pode experimentar ao ver as conexões existentes entre a vida (o modo de vida) que se vive e o sofrimento dos outros, pode ser compreendida em termos dessa pessoa estar atenta para esse aspecto do mundo, percebendo a relação existente entre as pessoas em virtude da nossa humanidade compartilhada. Ver o mundo sob este aspecto é vê-lo (apreendê-lo) como merecendo a vergonha. Pode-se tentar fazer com que outra pessoa veja estas mesmas conexões e sinta a vergonha. Podese tentar trazer a pessoa que não sente a vergonha para uma posição a partir da qual ela possa apreender o mundo desta maneira - como merecendo tal resposta - mas é ela que deve chegar a apreender o mundo desta maneira - ela deve vê-lo desta forma, por assim dizer.

Quando falamos do "mundo" neste contexto, nós não estamos falando do mundo desencantado ou "pré-conceptualizado" (dado), alegadamente o mundo das ciências naturais, mas antes do mundo conceptualizado. No entanto, ao falarmos do "mundo conceptualizado", nós não estamos falando do mundo como constituído por atos conceitualmente estruturados de pensamento, mas simplesmente de um mundo que é pensável. Pensamentos sobre o mundo, apreensões do mundo, são pensamentos com conteúdos pensáveis (ver McDowell Mind and World p. 28). Os conceitos pelos quais nós apreendemos o nosso mundo possuem propriedades normativas inseparáveis das suas propriedades descritivas. É com a percepção, a compreensão e o reconhecimento de tais propriedades que as nossas respostas emocionais ao mundo são obtidas ${ }^{7}$.

Por exemplo, quando alguém vê um evento como (digamos) vergonhoso (shameful), ele percebe uma relação interna entre o seu modo de apreender (ver) o evento - isto é, uma caracterização conceptual - e a sua concepção da vergonha. Tais relações internas podem emergir vivamente para nós por meio da formação de nossa natureza humana e a nossa segunda natureza (Bildung). Naquelas situações em que talvez não estivéssemos vivos para tais aspectos em um momento particular, poderíamos

7 Isto não deve ser lido como implicando a necessidade de se ter aprendido uma linguagem para que se experiencie a emoção.

Rev. Filos., Aurora, Curitiba, v. 28, n. 44, p. 689-716, maio/ago. 2016 
vir a sê-lo em um momento posterior, por meio do surgimento de um aspecto $^{8}$.

Vejamos um exemplo mais concreto. Léopard era um Hutu aprisionado (no momento da entrevista) o qual fora, segundo sua própria confissão, o perpetrador de crimes hediondos cometidos durante o genocídio de Ruanda em 1994. Não tendo sentido vergonha na época do genocídio, nem por certo tempo depois, ele conta para sua entrevistadora (Jean Hatzfeld) como mais tarde ele veio a sentir vergonha pelos crimes que cometera.

Alguns tentam mostrar remorso, mas tremem diante da verdade. Eles se esgueiram em torno dela, por causa dos muitos interessantes conflitantes, e acabam arremessados para trás.

Foi em um campo no Congo que eu senti pela primeira vez o meu coração doer. Eu orei, esperando encontrar alívio, mas em vão. Depois das orações ou dos hinos, a vergonha estava a minha espera, sem falta. Então eu comecei a me lamentar em voz alta, sem prestar atenção à zombaria expelida pela boca dos meus camaradas. Na prisão, eu contei toda a minha verdade. Ela saiu livremente. Desde então, sempre que alguém me pergunta, ela flui da mesma maneira.

(Hatzfeld 2005b: p. 154)

A vergonha de Léopard o surpreende no momento em que ele reconhece os seus crimes. É verdade que ele poderia ter admitido a culpa pelos atos que cometera já há algum tempo antes, mas apenas agora ele chega a um reconhecimento do seu crime. A vergonha parece ser uma parte constituinte deste reconhecimento. E a vergonha de Léopard surge apesar da zombaria de seus camaradas, os quais ainda devem reconhecer, ou os quais não reconhecem, o seu crime. Estes camaradas zombeteiros são a audiência imediata de Léopard, eles apresentam-se como os mais fortes candidatos a desempenhar aquele papel de grupo de honra (mais imediato), tão frequentemente invocado nas explicações da vergonha (ver Taylor, Op Cit). No entanto, não é diante do olhar

8 Eu não estou interessado em me atolar em discussões abstratas neste texto, então sugiro ver meu Shame and Philosophy para uma discussão mais detalhada. 
deles, por assim dizer, que Léopard sente sua vergonha, nem perante o tribunal que o julgou e o sentenciou. Léopard sente a vergonha a despeito daqueles que em seu entorno o ridicularizam, devido ao modo como ela o faz agir. Neste caso, como podemos de fato compreender a vergonha emergente de Léopard em seus próprios termos?

O processo de reconhecimento do seu crime é um processo pelo qual Léopard chega a um reconhecimento da mesma humanidade que ele compartilha com suas vítimas. Nós podemos compreender a vergonha e o remorso emergentes de Léopard ao compreendermos a sua passagem do não-ver para o ver as suas ações como os crimes morais que de fato são. Isso não significa dizer que ao perpetrar os seus crimes durante o genocídio, Léopard estivesse inconsciente ou negasse o status de suas ações como criminosas perante a lei internacional e doméstica. Mas podemos dizer que ele se afastou e negou aquilo mesmo que poderia obrigá-lo a reconhecer a significação moral de suas ações, negou e se afastou daquilo que permitiria a ele reconhecer o verdadeiro sentido de suas ações. Eu sugiro que se deva aqui dizer que ao proceder àquelas ações tal como ele o fez, Léopard não estava simplesmente violando um código ao qual estivesse sendo obrigado por uma autoridade externa, mas antes que a sua violência incidia sobre a própria trama das noções de humanidade e de existência humana e, assim, sobre a sua própria existência.

Na perpetração de seus crimes, Léopard recusou-se a reconhecer a humanidade de suas vítimas. Não é que ele se recusasse a admitir que a extensão do conceito de "ser humano" é "membro da espécie Homo Sapiens". Ao invés disso, ele se recusou a reconhecer e se afastou do significado de "ser humano" enquanto conceito moral com toda a sua riqueza normativa - poderíamos dizer. Ele passou por um processo durante o qual foi incapaz de reconhecer a humanidade dos outros - o que significa dizer que ele foi incapaz de ver as reivindicações morais de reconhecimento da humanidade que os outros nos colocam ${ }^{9}$.

9 Faço uso aqui de alguns trabalhos interessantes, embora talvez inesperados. Primariamente, Stanley Cavell (1979), The Claim of Reason, Seção 4. Ainda que eu também tenha sido inspirado pelo ensaio de Stephen Mulhall sobre o filme de Ridley Scott, Blade Runner: "Picturing the Human (Body and Soul)” e o texto de Rupert Read (2010): "Wittgenstein's Philosophical Investigations as a War Book".

Rev. Filos., Aurora, Curitiba, v. 28, n. 44, p. 689-716, maio/ago. 2016 
Léopard estava em um estado de negação quanto à humanidade daqueles que sujeitou à brutalidade, sofrimento e morte, e sendo assim, ao ser capaz de agir como agiu, ele também negou essa humanidade a si mesmo. Isto é o que afeta Léopard, as situações nas quais ele cometeu aqueles crimes não lhe haviam despertado vergonha porque ele ainda não havia visto tais atos como vergonhosos. Ao realizar aquelas ações, Léopard negou - estava em um estado de negação - a humanidade de suas vítimas e justificou assim a suspensão da ordem de "pré-genocídio" segundo a qual agir de tal maneira é desumano.

Na capa do livro de Jean Hatzfeld, no qual consta a entrevista com Léopard, há uma citação de Philip Gourevitch (o autor de outro livro de testemunhos comoventes sobre o genocídio: We Wish to Inform You That Tomorrow We Will Be Killed With Our Families). Gourevitch escreve: "a pungente documentação de Hatzfeld das vozes dos assassinos de Ruanda, nos lembra mais uma vez o quão perfeitamente humano pode ser, ser perfeitamente desumano". Esta pode, superficialmente, parecer uma observação desconcertante. No entanto, tendo compreendido as observações de Léopard citadas acima, podemos entender melhor este comentário de Gourevitch. A primeira ocorrência de "humano" na sentença denota, eu sugiro, "membro da espécie Homo Sapiens", a segunda, na locução "desumano", invoca o conceito moral de ser humano. Eu gostaria de sugerir que este último é o que testemunha a vergonha de Léopard, quando ela emerge, o que significa dizer que sua vergonha testemunha a sua incapacidade de escapar completamente do significado moral de "ser humano".

Poderíamos dizer que o significado moral de "ser humano" está internamente relacionado a - e carrega consigo - conceitos tais como dignidade, compaixão, e assim por diante. Dito de outra forma, teríamos dificuldades significativas para compreender o emprego do conceito moral do modo como ele é empregue ao falarmos de "humano" e "desumano", se não compreendêssemos também os conceitos de dignidade, compaixão, cuidado, e assim por diante. Poderíamos dizer, portanto, que uma boa maneira de se compreender, ou tornar perspícua, a capacidade de Léopard de cometer aqueles crimes sem sentir remorso ou vergonha até muitos anos mais tarde, é pensá-la em termos das relações internas mantidas, sob condições normais, entre 
o conceito moral de "ser humano" e conceitos tais como "dignidade", "cuidado", "compaixão" e "justiça", e no fato de estas relações estarem suspensas ou (talvez seja mais exato dizer) "latentes" por algum tempo, no caso de Léopard. Quando essas relações foram restabelecidas, quando vieram à vida, então a vergonha por seus atos pôde enfim emergir.

A questão que me interessa é esta: quais são as condições sob as quais estas relações encontram-se adormecidas, suspensas, suprimidas ou ausentes, de tal modo que a vergonha também esteja ausente? No que se segue, eu gostaria de sugerir quatro maneiras pelas quais isto pode acontecer. Eu não pretendo que esta seja uma lista exaustiva ou uma categorização de tipos, mas meramente uma maneira proveitosa de se trazer clareza para certas questões. Eu nomeio os quatro tipos de ausência da vergonha como o "tipo Kasper Hauser", o "tipo Diógenes de Sínope", o "tipo Mudança-de-Mundo" (World-Change type) e o "tipo Preconceito-relativo-a-Objetos" (Object-Prejudice type).

\section{Kaspar Hauser}

Minha primeira sugestão acerca do modo como a vergonha pode estar ausente empresta o seu nome da lenda de Kaspar Hauser. Eu aqui não estou preocupado com as especificidades do Kaspar Hauser histórico, mas sim com a figura da lenda, particularmente tal como apresentada no filme de Werner Herzog de $1974^{10}$.

Kaspar Hauser não estava sujeito ao grau de enculturação típico de seus pares. Ele foi mantido separado da cultura, que de outra forma teria sido a sua, ao ser isolado em uma cela durante os primeiros dezessete anos de sua vida. Exposto ao mundo social para além da cela, Kaspar não possuía, portanto, os recursos que permitem à vergonha manifestar-se em situações nas quais os seus pares esperariam que ela o fizesse ou, pelo menos, uma explicação sua de por que ela está ausente. Isso pode

${ }^{10}$ Eu não quero aqui me envolver em "Kasparologia", já que isto provavelmente me distrairia do meu real interesse. Entretanto, é amplamente aceito hoje em dia que os primeiros dezessete anos do verdadeiro Kaspar não poderiam ter sido como 0 quer a lenda - confinamento completo. Como eu 0 entendo, 0 consenso é o de que ele teria sido um idiota ou de que teria morrido depois de tais provações. 
manifestar-se de muitas maneiras: por exemplo, Kaspar grita de dor (ambas, física e psicológica) muito prontamente, não tendo aprendido que fazer algumas coisas em certas situações pode não ser apropriado.

A lenda de Kaspar Hauser representa para nós um caso extremo da falta de enculturação, talvez até mesmo uma caricatura sua. Ao assim fazê-lo, ela serve para ilustrar uma maneira pela qual a vergonha pode deixar de estar presente em uma situação ordinariamente esperada. Kaspar não foi exposto e não participou daquelas práticas que possibilitam a formação do caráter de uma pessoa a ponto de ela poder envergonhar-se. É claro que a cada dia que passa, enquanto habitante do mundo social - o mundo das normas compartilhadas, poderíamos dizer - ele desenvolve os pré-requisitos culturais os quais podem permitir-lhe ulteriormente experimentar a vergonha. Porém, de acordo com a lenda, ao ser libertado de sua cela aos dezessete anos ele não possui uma segunda natureza. A pessoa que sente vergonha é, portanto, antes de mais nada, um ser humano individual, particular, com uma história e uma esperança de futuro: uma pessoa; um indivíduo culturalmente investido vivendo com os outros em um mundo conceitualizado de normas compartilhadas; uma pessoa que possui uma segunda natureza. No dia de sua libertação, nós poderíamos caracterizar Kaspar como culturalmente e radicalmente alheio, transposto para este mundo sem os recursos culturais requeridos para se reconhecer ou se compreender as normas ou regras que constituem o mundo.

Poderíamos aqui contrastá-lo com uma pessoa que experimenta o medo (afetivo). Tal pessoa é, antes de mais nada, simplesmente um ser humano, com aqueles tipos de fraqueza humana característicos da espécie. Ela talvez seja uma pessoa, mas aqui, contrariamente à ênfase dada ao fardo cultural no caso da vergonha, ela agora recai sobre o modo como a pessoa é impelida pela consciência de sua existência de carne e osso e pela consciência de sua suscetibilidade à dor.

A lenda de Kaspar Hauser pode nos servir para ressaltar o quanto a ausência da vergonha pode ser de uma fonte cultural. Já que, por mais extremo que seja o caso de Kaspar, ele nos ajuda a destacar o fato de que a indexação da vergonha à nossa segunda natureza significa uma segunda natureza malformada que pode levar ou bem a um 
excesso ou bem a uma deficiência na vergonha. Podemos observar que o "tipo Kaspar Hauser" de ausência da vergonha parece ser passivo, na medida em que a ausência da vergonha é ocasionada por fatores principalmente externos à pessoa de quem normalmente esperaríamos que sentisse vergonha nesse tipo de cenário.

\section{Diógenes de Sínope}

O cognitivismo de "apreensão-do-mundo" propõe "redescrever" um episódio emocional ao tornar manifesto o modo como a pessoa que tem a emoção precisa estar atenta às relações internas entre certos conceitos relevantes, tais como sua concepção de si mesma como esta pessoa, e sua conceptualização da situação (aquilo que poderíamos chamar de cenário da vergonha).

Se pretendemos dizer que ver as relações internas, estar atento a elas, é uma maneira de caracterizar a vergonha sentida por alguém, então a classe contrastante, por assim dizer, é não ver, não estar atento a elas, no mesmo sentido em que Kaspar Hauser é incapaz de estar no momento em que é liberto de sua cela.

No entanto, há uma outra maneira semelhante, embora informativamente diferente, pela qual a vergonha pode estar ausente. Eu mencionei que no caso de Kaspar Hauser a ausência da vergonha era passiva, na medida em que fatores externos negaram-lhe os recursos para a vergonha. Isso sugere que pode haver uma maneira de acordo com a qual alguém pode ser impudente de um modo similar a Kaspar, mas ativamente. Aqui, a pessoa procura ativamente repelir a emoção da vergonha ao afastar-se e recusar o reconhecimento daquelas relações internas mantidas entre conceitos tais como vergonha, dignidade, ser humano, e assim por diante. Este é o despudor almejado pelos antigos cínicos. Eu tenho em mente, particularmente, Diógenes de Sínope, cuja propensão impudente para masturbar-se publicamente em pleno mercado de Atenas é discutida por Raymond Geuss: 
Diógenes de Sínope, que viveu no século IV a.C., tinha o hábito de se masturbar no meio do mercado Ateniense. Ele não era patologicamente inconsciente do seu ambiente, psicótico, ou simplório. Ele também não vivia em uma sociedade que estivesse nos primórdios daquilo que Elias chama de "processo de civilização"; isto é, ele não vivia em uma sociedade relativamente baixa na escala daquilo que tomamos como sendo nossa evolução cultural, uma em que tais formas de comportamento ainda não estivessem sujeitas à desaprovação sistemática e socialmente reguladas. Em vez disso, sabemos que os atenienses opunham-se ao seu modo de vida em geral e a esta forma de comportamento em particular. Eles claramente o consideravam um aborrecimento público e fizeramno conhecer a sua desaprovação. Sabemos disso porque a tradição doxográfica registra especificamente a resposta de Diógenes a uma crítica à sua masturbação em público. Ele teria respondido que desejava apenas que pudesse ser igualmente fácil satisfazer a fome ao se esfregar a própria barriga. (Geuss, 2003: p. 12-13).

Diógenes está deliberadamente afastando-se das relações internas as quais normalmente dão origem à vergonha de alguém que é visto masturbando-se em público. O seu ato é empreendido com a recusa em reconhecer a relação que há entre a repulsa dos outros relativamente a sua ação e o seu próprio ultraje (disgustingness) e, portanto, a sua falta de dignidade (enquanto ser humano). Ao recusar esse reconhecimento, a vergonha está ausente. Diógenes nega ativamente a vergonha. Esta depende de acedermos a um certo número de relações sofisticadas entre conceitos ao recusar-se reconhecer a aplicabilidade de um destes conceitos, Diógenes alcança o despudor.

O ponto a ser esclarecido aqui é o de que, ao contrário do "tipo Kaspar Hauser" de ausência da vergonha, Diógenes de Sínope wêe as relações, mas nega ativamente a significação de algumas delas, se recusa a reconhecê-las e recusa deixá-las pesar sobre ele, por assim dizer. Isso exige disciplina. Diógenes deve disciplinar-se quanto ao fato de que provocar repulsa nos outros não é o mesmo que ser repulsivo ou desprovido de dignidade, e nem mesmo possuir boas razões para sê-lo. Diógenes deve não apenas acreditar nisso, mas deve viver essa crença. Poderíamos dizer que ele deve ser a incorporação do seu pensamento. 
Relações como essas, entre a repulsa dos outros e a percepção de que se é uma pessoa repulsiva são coisas geralmente apreendidas, e sem necessidade de interpretação, negar tais relações, portanto, dá trabalho. Diógenes não pode simplesmente decidir julgar de modo diferente em qualquer que seja a ocasião. Não é que ele se recuse a reconhecer que os conceitos de ultraje e falta de dignidade estejam internamente relacionados ao conceito de vergonha, ao invés disso, ele se recusa a admitir, se recusando a reconhecer, que ele é repulsivo e desprovido de dignidade em virtude de suas ações provocarem repulsa nos outros. O despudor de Diógenes envolve, então, um "afastamento" ativo e uma negação daquela segunda natureza (Bildung) que invoca e ativa, as relações entre o significado da repulsa, a dignidade (humana) e a vergonha. Um tal "afastamento", uma tal negação, uma recusa de reconhecimento deste tipo, para que seja bem sucedida, precisa ser o produto de um treinamento em contra-enculturação. Precisa ser um processo por meio do qual o lugar que esses conceitos possuem na vida de alguém, a significação que possuem, torne-se fundamentalmente alterado. Neste sentido, Diógenes vê a sua segunda natureza, a sua Bildung, com a vergonha dela herdada, como tirânica, como restringindo sua liberdade natural (no sentido de primeira natureza).

O "tipo Diógenes" de ausência da vergonha ressalta o quanto a nossa enculturação não é uma questão inteiramente passiva, já que não é o caso de que sejamos, em algum sentido, determinados por nossa cultura relativamente às nossas respostas emocionais ao mundo. Mesmo aquelas emoções tais como a vergonha, as quais são indexadas a um nível elevado de especificidade cultural, podem ser controladas, com algum trabalho. Alguém poderia contestar os extremos a que chegou Diógenes de Sínope para abster-se de uma vergonha vista por ele como ilegítima, mas novamente, por ser um tanto extremo, o exemplo serve para ressaltar o papel significativo que possui a própria pessoa e o quanto ela pode ser responsável por sua vergonha ou por sua ausência. 


\section{Mudança-de-mundo}

Em minha discussão sobre Kaspar Hauser acima, eu observei que nós poderíamos ver a sua emergência ao mundo a partir de sua cela como algo semelhante a um indivíduo radicalmente alheio, que fosse transposto para esse mundo sem os recursos culturais requeridos para se reconhecer ou se compreender as normas ou regras que constituem o mundo da vida (lifeworld). Isso nos sugere uma terceira maneira pela qual a vergonha pode estar ausente. Aqui, é o mundo da vida que se modifica, por assim dizer. Colocado de outra maneira, no caso de Kaspar Hauser, o que o deixava desprovido dos recursos para a experiência da vergonha era a sua radical ausência de enculturação - de iniciação no mundo da vida; ele simplesmente não estava equipado para ver as relações entre os conceitos relevantes. Entretanto, diferentemente de Kaspar, nós poderíamos pensar em um cenário no qual a pessoa tivesse tido todos os recursos disponíveis para a sua enculturação, mas que em alguma fase de sua vida lamentavelmente se encontrasse em um contexto radicalmente diferente do seu contexto de enculturação. Aqui, é o (novo) mundo da vida que é radicalmente alheio, e é assim na medida em que ele viola as relações entre os conceitos, de modo que eles agora não se mantêm. Um caso deste tipo poderia ser aquele que tratamos acima ao falarmos de Léopard. Auschwitz é outro exemplo.

Auschwitz criou um novo conjunto de relações entre conceitos e, ao fazê-lo, sujeitou à violência as relações relativamente estáveis do mundo pré-Auschwitz - e, mais tarde, do mundo pós-Auschwitz. Claro, isso não significa negar os atos brutais de violência (em sentido literal) que lá ocorreram. Apenas, podemos chegar a uma melhor compreensão quanto à magnitude do crime cometido em Auschwitz, se pudermos ver também a maneira pela qual Auschwitz sujeitou igualmente à violência a habilidade das pessoas de responder emocionalmente ao seu mundo. 
O testemunho oral de Edith P., uma sobrevivente de Auschwitz e a entrevistada de Lawrence Langer, é aqui dolorosamente ilustrativo. Cito esta passagem porque as palavras de Edith P., e os comentários de Lawrence Langer a seu respeito, falam realmente com eloquência para o ponto que desejo salientar aqui ${ }^{11}$.

Edith P. [...] conta o caso de quando estava sofrendo severamente de disenteria, tendo "humanidade" o suficiente em si mesma, como ela relata, para impedir-se de aliviar-se dentro do alojamento. Ela estava muito envergonhada. Mas ela não podia ir até a latrina, porque uma ordem de Blocksperre havia sido emitida, um trancamento temporário dos alojamentos enquanto se realizava uma busca por dois reclusos desaparecidos. Ela violou a ordem mesmo assim e saiu, apenas para encontrar uma vigia SS particularmente brutal a qual, instruída de sua missão, imediatamente ordenou-lhe que voltasse e aplicou-lhe dez chicotadas nas costas com seu açoite. Embora tenha conseguido não chorar, Edith P. admite que ficou humilhada. Ela explica que a dor não era o problema. "A dor física você pode aguentar", diz ela, "mas como você pode suportar a dor emocional?"

A perda pública de dignidade de Edith e a concomitante dor emocional implicam um complexo sistema de motivos e efeitos amplamente além do seu controle. "Meu corpo se curou", ela confessa, "mas minha alma nunca se curou do fato de eu ter sido humilhada daquela maneira, na frente da minha família". (Sua cunhada e as três irmãs da cunhada testemunharam o açoitamento desde o alojamento) [...] Quando as "regras" mudaram em Auschwitz, quando Edith P. descobriu que a vergonha não fazia diferença porque ela não estava vinculada à dignidade tal como ela o havia suposto (nada disso tendo a ver com ela, é claro, mas com seus perseguidores), então a humilhação substituiu o orgulho. (Langer, 1991: p. 103).

Como Edith P. testemunha, funções humanas básicas tais como ir ao banheiro, estão agora relacionadas a episódios de profunda humilhação. Langer interpreta isto da seguinte maneira: “Quando as 'regras'

${ }^{11} 0$ leitor que se interessar pode encontrar uma versão estendida desta citação na seção conclusiva do capítulo final do meu Shame and Philosophy, onde a discuto por razões conexas, mas diferentes. A citação provém do (altamente recomendado) livro de Lawrence Langer Holocaust Testimonies: The Ruins of Memory. 0 que reproduzo aqui é o testemunho de Edith P. intercalado com o comentário de Langer a seu respeito, tal como aparece em seu livro. 
mudaram em Auschwitz, quando Edith P. descobriu que a vergonha não fazia diferença porque ela não estava vinculada à dignidade tal como ela o havia suposto (nada disso tendo a ver com ela, é claro, mas com seus perseguidores), então a humilhação substituiu o orgulho."

Não há vergonha em aliviar-se nos alojamentos porque não há dignidade na alternativa - uma surra/humilhação pública. Quando somos a cada passo privados da dignidade, então a vergonha penetra em cada um dos minutos da nossa existência e está, ou pelo menos pode estar, ausente. Porque, se a vergonha está sempre presente, se todo e qualquer curso de ação é vergonhoso, então nenhum ato particular pode ser distintivamente vergonhoso. Quando as regras (normas) pós-Auschwitz foram estabelecidas, nos anos seguintes à libertação, a vergonha pôde então retornar, porque a relação entre a vergonha e a dignidade também foi reestabelecida. Ela pôde novamente perceber a vergonha porque os seus contrastes no orgulho e na dignidade foram reestabelecidos igualmente.

Auschwitz sujeitou o conceito de "dignidade" - e, por extensão, o de "vergonha" - à violência. É claro que este é apenas um dos aspectos da violência perpetrada em Auschwitz (e em lugares de comparável trauma extremo), mas ele é um aspecto significativo. A dignidade de Edith P. lhe foi roubada em Auschwitz e quando as normas pós-Auschwitz possibilitaram a reemergência da dignidade e, deste modo, da vergonha, então a vergonha pôde ser sentida a respeito da completa privação de dignidade e de vergonha quando estivera forçada a viver pelas regras de Auschwitz.

Auschwitz serve então para ressaltar aquilo que eu estou chamando aqui de "tipo Mudança-de-mundo" de ausência da vergonha. É um exemplo de como um mundo brutalmente alheio de normas pode ser imposto, servindo então para alterar a própria trama da experiência de vida daqueles que estão sujeitos a esta imposição. Auschwitz e outros lugares de comparável atrocidade são versões extremas as quais, por serem tão extremas, nos ajudam a destacar a maneira pela qual "mudanças-de-mundo" menos extremas podem ter impacto sobre o nosso bem-estar emocional, nos negando a nossa própria capacidade de experienciar - neste caso - a vergonha. 
Até o momento, o meu foco incidiu sobre as maneiras segundo as quais os recursos para uma resposta à vergonha podem estar ausentes, tanto ativamente como com Diógenes de Sínope, quanto passivamente como nos outros dois tipos de ausência. A quarta maneira segundo a qual a vergonha pode estar ausente é um pouco diferente. Aqui, eu estou aberto à ideia de que a ausência da vergonha é algo que pode muito bem ser mais profundo do que a questão dos recursos culturais, que estão à disposição de uma pessoa (como no caso de Diógenes) e sua relação para com eles.

\section{Preconceito-relativo-a-Objetos}

Há muita discussão na filosofia contemporânea das emoções quanto à questão de saber até que ponto as emoções requerem objetos. Isto é, algumas vezes discutido em termos que investigam se as emoções são essencialmente ou caracteristicamente intencionais. Uma das razões para esta discussão está no fato de que, enquanto um grupo de teóricos, os cognitivistas, tomaram o objeto (formal) de cada emoção como um fator explicativo essencial e de caráter individuante, os seus oponentes fizeram questão de salientar que na verdade há exemplos de estados emocionais que não parecem ter objetos: a ansiedade é um exemplo frequentemente citado. Isto pareceu representar um problema para os cognitivistas a tal ponto, na verdade, que ele é citado por autores como Paul Griffiths (1997) como sendo um dos problemas insuperáveis enfrentados pelo cognitivismo, algo que, de acordo com tais críticos, deveria nos levar a vê-lo como um programa de pesquisa degenerativo.

A crítica e a dificuldade que os cognitivistas parecem ter para lidar com isso é, eu sugiro, equivocada. Já que se poderia sustentar que naqueles casos em que parece não haver objeto, nós não estaríamos obrigados a admitir que esta é uma emoção sem objeto (objectless emotion). Em vez disso, eu sugiro que os episódios emocionais que parecem vazios podem ser vistos como tendo um objeto que apenas é difuso e complexo, o qual, sendo assim, nos passa despercebido em nossa busca. Ao assim proceder, e então fracassar na procura (por um 
objeto simples), nós manifestamos um preconceito filosófico contra objetos difusos complexos (complex diffuse objects).

Eu gostaria de sugerir que este preconceito tem outras implicações práticas para além daquelas que possa ter na avaliação dos méritos ou deméritos das teorias da emoção. Note-se, portanto, que há momentos em que podemos ser capazes de oferecer uma razão (rationale) para um sentimento de vergonha, ou para o medo, ou para a raiva, e ainda assim a emoção não se fazer presente. Parece que a presença de uma razão simplesmente não é suficiente, mesmo que a pessoa no cenário da vergonha (ou no cenário do medo ou da raiva) venha a aderir a tal razão. Isso difere dos nossos três tipos anteriores de ausência da vergonha, em que não há explicação da ausência em termos das relações mantidas ou não, sendo reconhecidas ou negadas, entre os conceitos relevantes. Na situação que eu desejo discutir aqui, podemos então supor que não estamos lidando nem com um Kaspar Hauser, nem com um Diógenes de Sínope ou com uma "mudança-de-mundo". Contudo, a vergonha ainda está ausente mesmo quando podemos prover uma razão clara para que ela esteja presente.

Neste caso, como é que isso acontece? Nós consideraremos abaixo alguns potenciais candidatos a objetos da vergonha. Primeiramente, no entanto, duas notas de advertência.

1. Não há qualquer reivindicação normativa sendo feita aqui. A lista a seguir é descritiva, na medida em que compreende objetos da vergonha os quais são facilmente encontrados com a realização de uma pesquisa sobre as possíveis expressões da vergonha. Existem algumas inscrições nesta lista que se poderia tomar acertadamente como um indicativo de distorções culturais perversas das sensibilidades morais. A vergonha, poderíamos observar, pode servir como um barômetro cultural: ela nos indica as maneiras sutis de formação do caráter nas quais a nossa cultura opera abaixo do nosso radar, por assim dizer. O liberal que ri de uma piada racista e é depois consumido pela vergonha quando reflete a respeito (ou quando sobre isto é contestado, ou tendo sido visto rindo) serve para nos mostrar que, em um nível profundo em nossa cultura, existem ainda suposições preconceituosas a respeito das pessoas que possuem diferentes níveis de pigmentação 
da pele (e assim por diante) e que o modo como a nossa cultura nos apresenta o mundo da vida - através da enculturação - está em descompasso (e atraso) relativamente às atitudes expressas por seus indivíduos mais progressistas. A vergonha do nosso "hipotético liberal" testemunha a necessidade de se modificar as atitudes de baixo para cima e significa modificar práticas, a maneira como empregamos certas categorias ao nos comunicarmos, e assim por diante.

2. As inscrições da lista não são categorias mutuamente excludentes.

Objetos potenciais da vergonha:

a) pintura que eu acabei de terminar (e que é de baixa qualidade);

b) meu corpo nu exposto (que eu acabei de expor involuntariamente a um desconhecido);

c) meu caráter moral (que é visto pelos outros como / eu agora aceito, como estando aquém da minha apresentação / suposições sobre este caráter);

d) minha dignidade (que eu agora vejo que não consegui preservar / que me é negada);

e) minha irmã (que foi estuprada e cuja resultante perda de castidade macula toda a família);

f) o mundo da vida do qual faço parte (que eu agora vejo como repugnantemente inumano por ser tão sistematicamente injusto);

g) a humanidade (que não consegue agir coletivamente e efetivamente para impedir a sua própria destruição e a destruição do ecossistema do qual faz parte, apesar de conhecer a ameaça e a solução) ${ }^{12}$.

Agora, ao trabalharmos esta lista de cima para baixo, percebemos que os objetos tornam-se mais complexos e difusos e, assim, mais difíceis de se apreender. As inscrições " $\mathrm{f}$ " e " $\mathrm{g}$ " tomam o "mundo da vida" e a "humanidade" como o objeto da vergonha. Isso pode, eu sugiro, não apenas levar alguém a pensar que em tais situações não há

12 Este ponto é explorado em relação a um conjunto diferente de questões (embora com alguma sobreposição) em Hutchinson, P. e Read, R. “Practicing pragmatist-Wittgensteinianism": The Cambridge Companion to Pragmatism, 2013. 
objeto, como pode também levar a uma ausência da vergonha. Já que, embora possamos muito bem aderir à razão dada para a vergonha, tal como apresentada nas inscrições " $\mathrm{f}$ " e " $\mathrm{g}$ " da lista, nós ainda assim poderíamos não sentir vergonha.

Tomemos um exemplo atual. Eu o escolho precisamente porque o seu status enquanto atrocidade será questionável para muitos leitores. Vou começar por discutir o medo e então progredir para uma discussão sobre a vergonha.

Um dos problemas para a nossa motivação (como uma sociedade, como uma espécie) para fazer as mudanças requeridas a fim de mitigar ou prevenir catástrofes climáticas como um resultado do aquecimento global antropogênico (AGA), tais como a radical mudança em nossas culturas de finalmente passar para uma economia "estacionária" de baixa emissão de carbono ou livre de carbono, é justamente que o problema do AGA é muito difuso. Não há um objeto claro a temer, e o medo precisa de um objeto. Dito de outra maneira, o medo diante de uma ameaça à nossa existência é uma resposta caracteristicamente emocional: nós vemos uma cobra no caminho em que estamos seguindo e sentimos medo, mesmo que mais tarde venhamos a nos lembrar de que as cobras deste local não constituem qualquer ameaça.

Em uma abordagem (neo-) Jamesiana, anti-cognitivista, nós poderíamos caracterizar o problema do AGA da seguinte maneira: a ameaça imposta pelo AGA, e a nós explicada pelas ciências climáticas via meios de comunicação, é simplesmente insuficiente para determinar os gatilhos ambientais que poderiam desencadear a nossa resposta fisiológica (sensações, mudanças no sistema nervoso autônomo - SNA), cujas respostas emocionais, em uma abordagem Jamesiana, são a sua consciência. Agora, se tomamos aqui uma abordagem puramente Jamesiana, então nada há que possamos fazer a respeito, a não ser esperar até que haja algum evento de magnitude tal que esteja inequivocamente relacionado às mudanças climáticas, e que venha a servir como um gatilho ambiental. O problema com uma abordagem como a de sentar e esperar é que, ao aguardarmos por um tal evento - um Pearl Harbour ambiental - talvez venhamos a esperar até que seja tarde demais (para se prevenir um superaquecimento fatal incontrolável). 
Pela abordagem cognitivista, parece difícil dar um sentido à nossa inação. A ciência é inequívoca, o princípio da precaução invoca motivos racionais para se agir imediatamente, e mesmo assim nós simplesmente estamos deixando de agir de qualquer maneira significativa. Certamente, uma compreensão da ciência nos levaria a uma formação de crenças avaliativas, de tal forma que viéssemos a temer as consequências de não se agir para mitigar as mudanças climáticas e, assim, tomar medidas para ausentar esse medo. No entanto, parece que falta aqui o medo enquanto um estado emocional.

O problema, eu sugiro, é o problema dos objetos difusos. A nossa constituição emocional/psicológica de seres humanos parece preconceituosamente favorecer objetos simples com os quais estamos diretamente familiarizados. A ameaça imposta pelo AGA, embora não menos real, é como uma ameaça que nós poderíamos caracterizar como tendo um objeto difuso complexo.

O que é preciso para se motivar a ação é um reconhecimento engajado do problema que enfrentamos. O problema de como mitigar o AGA - sendo ele complexo e difuso - parece afastar qualquer possibilidade de uma tal resposta "engajada", e tanto a abordagem cognitivista (ortodoxa) da emoção quanto a abordagem empirista Jamesiana são incapazes de nos ajudar a compreender e a realizar a mudança requerida.

\section{Considerações finais}

Eu gostaria de sugerir que o "cognitivismo de apreensão-do-mundo" nos ajuda no sentido de que ele rejeita a implicação Jamesiana de que as emoções são passivas (essencialmente afetivas), proporcionando ao mesmo tempo uma maneira de se compreender o modo como elas podem constituir respostas a um mundo significativo, sem daí se inferir que elas sejam escolhidas. O que significa isto para nós em termos práticos? Bem, tal abordagem poderia nos mostrar como enquadrar melhor a maneira pela qual comunicamos a ameaça, de modo a trazer a resposta integrada e engajada que requeremos. Ela pode nos 
mostrar o tipo de pré-requisitos culturais envolvidos para aqueles indivíduos que estão em uma posição na qual e devido à qual reconhecem a ameaça imposta pelo AGA.

Nós deveríamos sentir vergonha, nós (particularmente aqueles dentre nós que vivem no Ocidente) somos atores em uma atrocidade. Somos uma parte e temos um papel no desenrolar desta atrocidade o qual é muito maior do que se poderia argumentar relativamente àqueles que foram tomados pela vergonha ao sobreviver a atrocidades anteriores (pessoas tais como Primo Levi). Dito de outra maneira, somos agentes desta atrocidade, e não simplesmente vítimas ou vítimas em potencial, o nosso estilo de vida esbanjador de carbono nos assegura disso. Então, por que a ausência de vergonha?

O meu ponto é que a vergonha pode estar ausente, quando deveríamos esperar que ela estivesse presente, porque a natureza complexa e difusa do objeto desta vergonha nos leva a (ou nos permite) um desengajamento emocional (um desengajamento do objeto, poderíamos dizer). Ao mesmo tempo, não encontramos nenhum problema em fornecer uma razão para a vergonha estar de fato presente, ela apenas não está aí. Além disso, nós nos engajamos em numerosos estratagemas de negação para manter qualquer vergonha latente à distância.

Certamente, eu estou falando aqui de alguém que seja experiente o suficiente para ver a razão para a vergonha: alguém que compreenda a ciência climática, compreenda as mudanças requeridas em nosso modo de vida, e que compreenda as consequências, tanto para os humanos quanto para o ecossistema, da não realização de tais mudanças.

Claro, há outras maneiras conforme as quais a vergonha pode estar ausente neste contexto, poderíamos não sentir vergonha primariamente por ignorância, mas isto seria então diferente: uma versão do “tipo Kaspar Hauser". Poderíamos não sentir vergonha por estarmos em um estado de negação, e esta seria uma versão do "tipo Diógenes de Sínope". Poder-se-ia também argumentar que muitos não sentem vergonha diante do nosso fracasso em agir para mitigar o AGA, porque a nossa cultura não nos prepara para isso.

As discussões a respeito da atrocidade estão, muitas vezes, intimamente ligadas a discussões sobre a vergonha que resulta da 
exposição àquelas atrocidades. Em certo sentido, a vergonha que emerge de uma exposição à atrocidade é parte do que identifica o evento como atroz. O que eu gostaria de argumentar é que quando a vergonha está ausente, esta ausência pode servir para nos cegar para a atrocidade que está diante de nós e que é nosso dever impedir. Sentir vergonha faz parte de ver a atrocidade pelo que ela é, de uma maneira apropriada e emocionalmente engajada. Ela é, assim, uma parte vital de ser humano, e sua ausência em casos tais como aqueles que acabo de descrever, é uma insuficiência demasiadamente humana de humanidade. Esperase que não seja fatal.

\section{Referências}

CAVELL, S. The claim of reason. Oxford: Oxford University Press, 1979.

DEIGH, J. "Cognitivism in the Theory of Emotions." Ethics, 104 (1994), p.824-854.

GEUSS, R. Public goods, private goods. Princeton: Princeton University Press, 2003.

GOLDIE, P. The emotions: a philosophical exploration. Oxford: Oxford University Press, 2000.

GOUREVITCH, P. We wish to inform you that tomorrow we will be killed with our families. London: Picador, 2000.

GRIFFITHS, P. E. Basic Emotions, Complex Emotions, Machiavellian Emotions. In: Philosophy and the emotions. Edited by Anthony Hatzimoysis. Cambridge: Cambridge University Press, 2003, p. 39-68.

GRIFFITHS, P. E. The degeneration of the cognitive theory of emotion. Philosophical Psychology 2, n. 3, 1989, p. 297-313.

GRIFFITHS, P. E. What emotions really are. Chicago: Chicago University Press, 1997. 
GUSTAFSSON, Y.; KRONKVIST, C.; MCEACHRANE, M. (Eds.). Emotions and understanding. Basingstoke: Palgrave MacMillan, 2009.

HATZFELD, J. Into the quick of life: the Rwandan genocide: the survivors speak. London: Serpent's Tail, 2005.

HATZFELD, J. A time for machetes: the Rwandan genocide: the killers speak London: Serpent's Tail, 2005.

HATZIMOYSIS, A. (Ed.). Philosophy and the emotions. Cambridge: Cambridge University Press, 2003.

HUTCHINSON, P. "Emotion-Philosophy-Science." In: Emotions and understanding, edited by Yiva Gustafsson, Camilla Kronkvist, and Michael McEachrane. Basingstoke: Palgrave MacMillan, 2009, p. 60-80.

HUTCHINSON, P. Shame and philosophy: an investigation in ethics and the philosophy of emotion. Basingstoke: Palgrave MacMillan, 2008.

HUTCHINSON, P.; READ, R. "Practicing pragmatist-Wittgensteinianism". In: The Cambridge Companion to Pragmatism, edited by A. Malachowski. Cambridge: Cambridge University Press, 2013, p. 159-188.

JAMES, W. What is an emotion? Mind, v. 9, n. 34, p. 188-205, apr., 1884.

LANGER, L. L. Holocaust testimonies: the ruins of memory. New Haven: Yale University Press, 1991.

LEVI, P. The drowned and the saved. London: Abacus, 1989.

LEVI, P. If this is a man/the truce. London: Everyman's Press, 2000.

LEVI, P. The Voice of memory: interviews 1961-1987. Edited by Marco Belpoliti and Robert Gordon. Cambridge: Polity, 2001.

MCDOWELL, J. Mind and world. Cambridge: Cambridge University Press, 1994.

MULHALL, S. Picturing the human (body and soul): a reading of blade runner. Film and Philosophy 1, n. 1, p. 87-104, 1994. 
NUSSBAUM, M. Upheavals of thought: the intelligence of emotions. Cambridge: Cambridge University Press, 2003.

READ, R. "Wittgenstein's philosophical investigations as a war book". New Literary History 41, p. 593-612, 2010.

TAYLOR, G. Pride, shame, and guilt: emotions of self-assessment. Oxford: Oxford University Press, 1985.

Recebido: 06/06/2016

Received: 06/06/2016

Aprovado: 09/06/2016

Approved: 06/09/2016 